\title{
Dietary Control of Ganglioside Expression in Mammalian Tissues
}

\section{Tetsuya Okuda}

Bio-Design Research Group, Bioproduction Research Institute, National Institute of Advanced Industrial Science and Technology (AIST), Tsukuba 305-8566, Japan; t-okuda@aist.go.jp; Tel.: +81-50-3648-6162

Received: 27 November 2019; Accepted: 24 December 2019; Published: 26 December 2019

\begin{abstract}
Gangliosides are series of glycosphingolipids containing sialic acids in the oligosaccharide portion in mammalian cells. Gangliosides are a component of cellular membranes and play roles in modulating membrane function and the activity of membrane proteins. Abnormal expression and metabolism of gangliosides lead to the onset of several conditions in humans, such as neurologic diseases, diabetes, and cancer. A number of studies have been carried out to date to investigate the role of gangliosides in these diseases, and the effect of diet on tissue expression of gangliosides has recently become a topic of interest in this field. As gangliosides are degraded in the intestinal tract, ingested food-derived gangliosides are not directly absorbed into tissues in vivo, but the degradation products can be absorbed and affect ganglioside expression in the tissues. Recent studies have also shown that the expression of gangliosides in tissue cells can be indirectly induced by controlling the expression of ganglioside metabolism-related genes via the diet. These results indicate that dietary control can regulate the expression levels of gangliosides in tissues, which is expected to play a role in preventing and treating ganglioside-related diseases. This review introduces recent studies on the effect of diet on the expression of gangliosides in tissues, with a focus on our findings.
\end{abstract}

Keywords: ganglioside; glycosphingolipid; ketogenic diet; low-carbohydrate diet; epilepsy

\section{Introduction}

Glycosphingolipids are amphipathic molecules composed of oligosaccharides and ceramides and function as a component of cellular membranes in mammalian cells. The oligosaccharide and ceramide portion of glycosphingolipids exhibit structural diversity, and various molecular species of glycosphingolipids have been defined based on differences in their oligosaccharide structures in mammalian cells [1]. 'Ganglioside' is a general term to describe an acidic glycosphingolipid containing sialic acid in the oligosaccharide portion, and because it is abundant in ganglia, it was designated as ganglioside.

Gangliosides interact with co-localized proteins in cellular membranes and modulate cellular functions, particularly signal transduction [1,2]. An optimal level of ganglioside expression is required to maintain membrane integrity [3]. Indeed, abnormal expression of gangliosides in tissue cells is associated with a variety of diseases, such as diabetes [4], neurologic diseases [5], and cancer [6]. Thus, a number of studies have been conducted to enhance understanding of the biosynthesis and metabolism of gangliosides as new targets for the prevention and treatment of these diseases.

Little is known regarding the effect of diet on ganglioside expression in vivo; thus, several investigations are now underway to address this issue. The results of related previous studies indicate that gangliosides are degraded in the intestinal tract, and ingested food-derived gangliosides are thought to be indirectly absorbed in the tissues in vivo [7]. Ingestion of saccharides and lipids, which are components of gangliosides, can affect their tissue expression levels [7-9]. Furthermore, a recent study demonstrated that diets/foods that affect the expression of ganglioside 
metabolism-related genes alter ganglioside metabolism in tissue cells as well as ganglioside expression levels [10].

In this review, we comprehensively discuss recent related studies examining the effect of diet on the expression of gangliosides in tissue cells, with a focus on our research results.

\section{Structures and Molecular Species of Gangliosides}

Gangliosides are produced by animal cells, including those of humans and mice. Figure 1 shows the structures and synthesis pathways of the major molecular species of gangliosides produced in mammalian cells. Gangliosides are composed of a series of glycosphingolipids, which include a number of molecular species defined based on differences in oligosaccharide structure. Ceramides (sphingoid base and fatty acid), which are associated with the immunogenic activity of glycosphingolipids, also exhibit structural diversity [11-13].

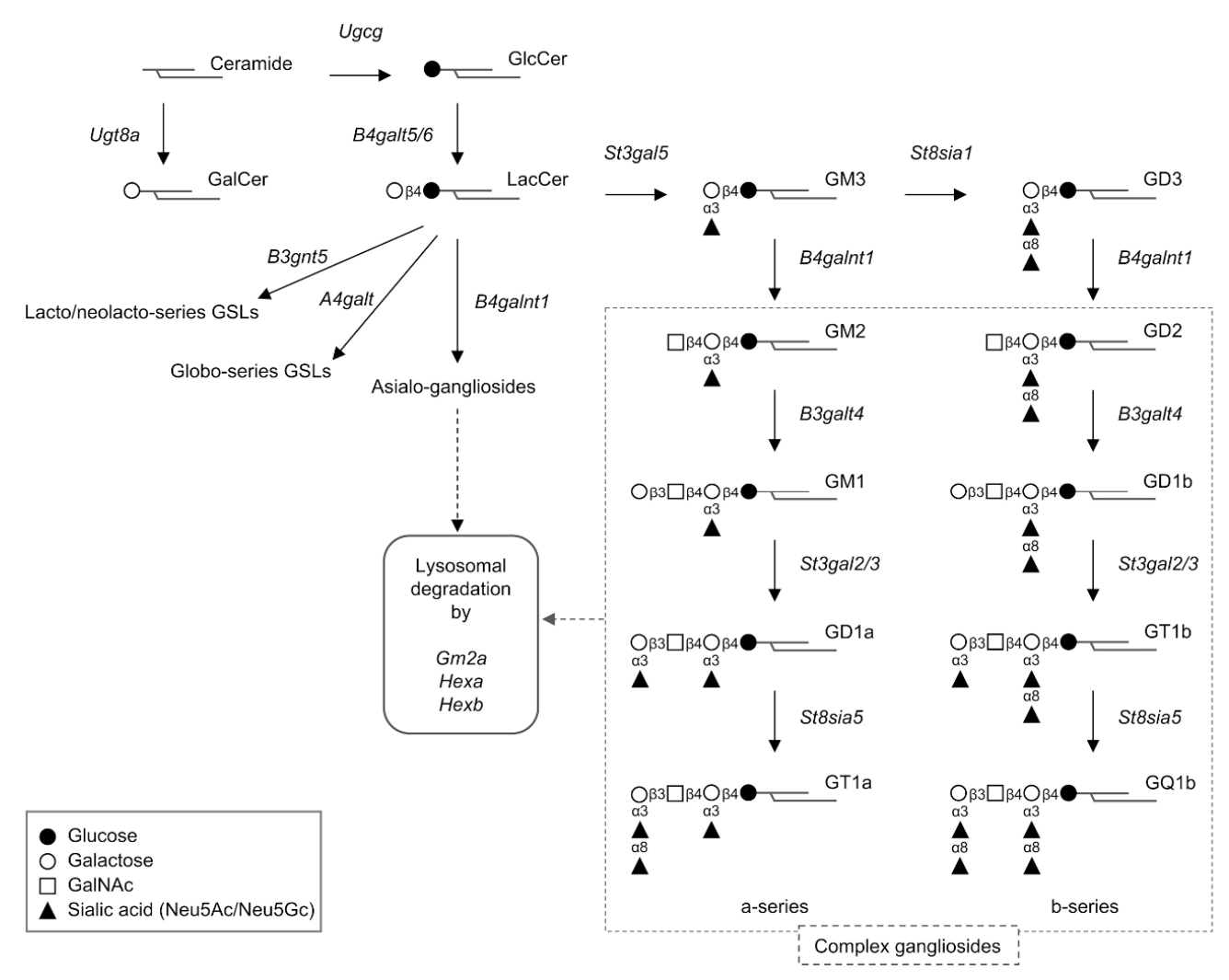

Figure 1. Schematic illustration of the primary metabolic pathway of mammalian gangliosides. Genes encoding proteins involved in ganglioside synthesis and degradation are shown in italics. Solid-line arrows indicate synthetic pathway. Dotted-line arrows indicate degradation pathway.

Each molecular species of ganglioside is expressed differently in different animal species and cell types, and the oligosaccharide portion exhibits antigenicity on the cell surface. As different oligosaccharide structures of gangliosides have different immunogenicity, they can be used as specific antigens to differentiate animal species and cell types $[13,14]$. Moreover, the oligosaccharide structure can change depending on the differentiation or pathologic state of a cell. These oligosaccharides are known as differentiation or pathologic cell markers.

The diversity of ganglioside structures is determined by the ganglioside metabolism-related genes expressed in the cell [1,2]. In particular, the diversity of oligosaccharides is strictly controlled by the activity of several enzymes encoded by different glycosyltransferase genes. Thus, the expression of a particular molecular species of glycosphingolipid in cells and tissues can be altered by manipulating the expression of specific glycosyltransferase genes. Cancer cells express glycosphingolipid molecular 
species that are cancer-specific antigens not found in noncancerous parental cells [6]. The expression of these glycosphingolipids is due to the expression of glycosyltransferase genes encoding specific enzymes that mediate their synthesis in conjunction with the oncogenic transformation of the parent cells.

\section{Role of Gangliosides in Cellular Function}

Although the role of glycosphingolipids in regulating cellular functions is not fully understood due to difficulties in analyzing these molecules, several studies using genetically engineered cells and mice have shown that gangliosides interact with co-localized proteins in cellular membranes and function as modulators (Table 1). In particular, the role of glycosphingolipids as regulators of receptor-type tyrosine kinases has been intensively investigated. For example, monosialoganglioside GM3 regulates signal transduction mediated by epidermal growth factor (EGF) via inhibition of the tyrosine kinase activity of the EGF receptor in the cell membrane [15]. In contrast, disialoganglioside GD3 promotes cellular signal transduction by interacting with several signaling proteins, such as Lyn, transient axonal glycoprotein-1 (TAG-1), p130Cas, and paxillin [6,16-18]. Differential expression of various molecular species of gangliosides in each cell type appear to regulate different cellular responses through interactions with membrane proteins specifically expressed in that cell type.

Table 1. Gangliosides and their interacting proteins.

\begin{tabular}{ccc}
\hline Ganglioside & Interacting Protein & Reference \\
\hline GM3 & $\begin{array}{c}\text { EGF receptor } \\
\text { Insulin receptor }\end{array}$ & {$[15]$} \\
{$[4,19,20]$} \\
\hline GD3 & $\begin{array}{c}\text { p130Cas, paxillin } \\
\text { Lyn, TAG-1 }\end{array}$ & {$[18]$} \\
& NGF receptors & {$[216,17]$} \\
\hline GM1, GD1a, GD1b, GT1b & Leptin/Ob receptor & {$[3,24]$} \\
\hline GM1, GD1a & Leptin & {$[25]$} \\
\hline
\end{tabular}

EGF, epidermal growth factor; TAG-1, transient axonal glycoprotein-1; NGF, nerve growth factor.

Gangliosides with complex oligosaccharide structures (complex gangliosides) are the primary components in tissues of the central nervous system and modulate the functions of membrane proteins in neurons. For example, ganglioside GM1 modulates signal transduction in neuronal membranes via nerve growth factor receptors to promote neuronal differentiation [21,22]. Furthermore, the polysialylated complex gangliosides GD1b and GT1b exhibit the potential to promote neuronal cell proliferation [23].

Loss of gangliosides, by contrast, perturbs signal transduction through the leptin receptors and insulin receptors expressed in neurons in the hypothalamus [3]. In the forebrain of neuron-specific ganglioside-deficient mice, leptin/leptin receptor signal transduction is attenuated in the hypothalamic neuronal membrane, which results in dysregulation of body energy homeostasis and the development of obesity. Analyses of mice lacking part of the oligosaccharide structure of gangliosides demonstrated that a-series gangliosides (Figure 1) positively regulate the leptin receptor to mediate signaling in hypothalamic neurons [24]. Increased mediobasal hypothalamus insulin signaling suppresses white adipose tissue lipolysis [26]. Insulin-associated signal transduction in hypothalamic neurons is also dysregulated in ganglioside-deficient mice, and the phenotype of these mice indicates that hypothalamic gangliosides modulate insulin receptor signaling and protein levels. The loss of hypothalamic gangliosides enhances insulin signaling and results in a decrease in fasting-induced lipolysis. It was also shown that gangliosides are required for the secretion of leptin from adipocytes into the blood [25]. These findings indicate that decreased expression of gangliosides in hypothalamic neurons and adipocytes promotes the progression of obesity and the onset of diabetes.

In the mammalian immune system, neutral glycosphingolipids containing very-long-chain fatty acids in the ceramide portion function as mediators of inflammatory signaling [27] as well as innate 
and acquired immunity [11-13,28]. As loss of gangliosides has been associated with abnormal immune responses [29], gangliosides containing very-long-chain fatty acids may exhibit similar effects in the mammalian immune system.

\section{Gangliosides and Disease}

Lysosomal disease, a hereditary disease characterized by abnormal accumulation of gangliosides in the tissues, was discovered more than 50 years ago [30], and since then there have been a number of studies examining the relationship between gangliosides and disease (Table 2). In recent years, many membrane proteins that interact with gangliosides have been identified, spurring research into the relationship between these interactions and various diseases. These studies demonstrated that abnormal expression of gangliosides is a molecular basis for the onset of diseases such as diabetes [4], central nervous system diseases [5], and cancer [6].

Table 2. Ganglioside-related diseases.

\begin{tabular}{ccc}
\hline Ganglioside & Related Disease & Reference \\
\hline \multirow{2}{*}{ GM3 } & Type 2 diabetes mellitus & {$[4]$} \\
& Epilepsy & {$[31]$} \\
\hline \multirow{2}{*}{ GM2 } & GM2 gangliosidosis & {$[30]$} \\
& Spastic paraplegia & {$[32]$} \\
\hline \multirow{2}{*}{ GM1 } & GM1 gangliosidosis & {$[30]$} \\
& Alzheimer's disease & {$[33]$} \\
\hline GM1, GD1a & Obesity & {$[3,26]$} \\
\hline GD3, GD2 & Melanoma, other cancers & {$[6]$} \\
\hline
\end{tabular}

With regard to diabetes, the effect of GM3 on insulin signaling has been thoroughly investigated [4]. Several experimental models demonstrated that GM3 ganglioside interacts with insulin receptors in the cellular membrane to negatively regulate signal transduction. Abnormal accumulation of GM3 was shown to induce insulin resistance in cells, which is the molecular basis of the pathology of type 2 diabetes [19]. Accumulation of GM3 is triggered by the chronic inflammatory stimulation of cells which is associated with a pathology of type 2 diabetes [20].

Regarding neurologic diseases, humans harboring a mutation in the GM3 synthase gene, which encodes a key enzyme involved in the synthesis of the backbone structure of gangliosides, reportedly develop autosomal recessive infantile-onset symptomatic epilepsy syndrome [31]. Hereditary spastic paraplegia is known to be associated with mutations in the B4galnt1 gene encoding GM2/GD2 synthase, a rate-limiting enzyme in the synthesis of the complex gangliosides abundant in central nervous system tissues [32]. Genetically engineered mice lacking complex gangliosides also exhibit various neurologic symptoms.

Gangliosides expressed on the cell surface serve as receptors for certain viruses and bacterial toxins and thus mediate infection and cytotoxicity. For example, tetanus toxin enters neurons via gangliosides from the neuromuscular junction [34]. The tetanus toxin molecules are transported to central nervous system tissue via axonal transport, where they disrupt the release of neurotransmitters from neuronal synapses, resulting in spastic paraplegia. Patients with ganglioside storage disease can develop a variety of neurologic disorders [30]. It was suggested that GM1 ganglioside accumulates in senile plaques in Alzheimer's disease, and these plaques serve as scaffolds for accelerated amyloid- $\beta$ aggregation, which is the molecular pathology of this disease [33]. These findings indicate that the central nervous system tissues, such as the brain, require appropriate amounts of gangliosides to remain in a healthy condition.

Since certain gangliosides were discovered as cancer-specific antigens [6,13,15,35], additional studies have examined the role of gangliosides specifically expressed in cancer cells. Oncogenic transformation alters the expression levels of glycosyltransferase genes, resulting in 
upregulated expression of cancer-specific gangliosides. Studies using genetically engineered cells have shown that cancer-specific gangliosides modulate signal transduction involved in cancer growth and metastatic potential.

\section{Diet and Ganglioside Expression}

A number of studies are currently underway examining the effect of diet on the expression level of tissue gangliosides. Although the details remain to be fully elucidated, recent progress has revealed new information regarding the effects of diet on ganglioside dynamics, metabolism, and induction. Cellular responses to nutrients and stress have also been identified as factors involved in the regulation of tissue ganglioside expression. This section describes these findings.

\subsection{Gangliosides in Foods}

Gangliosides are found in animal-derived foods such as meat, fish, egg yolk, and dairy products. The composition of molecular species of gangliosides in these foods are listed in Table 3. Dairy products primarily contain GD3 [36], but meat and fish contain GM3 [37]. These foods also contain complex gangliosides as minor components. Complex gangliosides are major lipid components in animal brains used as food in certain cultures.

Table 3. Ganglioside components in foods.

\begin{tabular}{|c|c|c|c|}
\hline \multicolumn{2}{|c|}{ Food } & $\begin{array}{c}\text { Major (Minor) Ganglioside } \\
\text { Component }\end{array}$ & Reference \\
\hline \multirow{4}{*}{ Meat } & Beef & GM3 (GD3, GD1a) & [37] \\
\hline & Pork & GM3 (GD3, GD1a, GD1b) & [37] \\
\hline & Chicken breast & GM3 (GD3) & [37] \\
\hline & Chicken thigh & GM3 (GD3, GD1a, GD1b) & [37] \\
\hline \multirow{5}{*}{ Fish } & King salmon & GM3 (GD3) & [37] \\
\hline & Snapper & GM3 (GD3, GD1a, GD1b) & [37] \\
\hline & Island mackerel & GM3 (GD3, GD1a, GD1b) & [37] \\
\hline & Turbot & GM3 (GD3, GD1a, GD1b, GT1b) & [37] \\
\hline & Tuna & n.d. & [38] \\
\hline \multicolumn{2}{|c|}{ Egg yolk } & n.d. & [38] \\
\hline \multirow{3}{*}{ Human breast milk } & Early stage & GD3 & {$[39,40]$} \\
\hline & Late stage & GM3 & {$[39,40]$} \\
\hline & All stages & (GM1 and others) & [40-42] \\
\hline \multirow{6}{*}{ Dairy products } & Bovine milk & GD3 (GM3) & [43] \\
\hline & Bovine butter & GD3 (GM3) & [36] \\
\hline & Yogurt & n.d. & [38] \\
\hline & Infant formula & GD3 (GM3) & {$[43,44]$} \\
\hline & Cheddar cheese & n.d. & {$[38]$} \\
\hline & Whey & GD3 (GM3) & {$[44]$} \\
\hline \multicolumn{2}{|c|}{ LCKD (Bio-Serv F3666) } & GD3 (GM3) & This article \\
\hline
\end{tabular}

GD3 is the major ganglioside in human breast milk during the early lactation stage, whereas GM3 becomes the major ganglioside in later stages [39,40]. Some complex gangliosides are also found in breast milk [40-43]. Bovine milk contains GD3 as the major ganglioside, and therefore, formula prepared using bovine milk also contains this ganglioside [43]. Gangliosides can remain stable in breast milk for long periods at several storage temperatures [45]. Pasteurization has almost no effect on the stability of gangliosides in breast milk.

Plants and fungi contain almost no sialic acid and therefore do not contain gangliosides. However, edible plants such as soybean, corn, rice, wheat, and konjac (Amorphophallus konjac, K. Koch) are rich in glucosylceramide [46,47], a ganglioside precursor. Although not used as a food source, marine sponge 
(Agelas mauritianus) contains a neutral glycosphingolipid, $\alpha$ GalCer, which activates innate immune responses in mammals [28].

\subsection{Digestion and Absorption of Gangliosides in Foods}

Gangliosides contained in foods are degraded in the intestinal tract (Figure 2), and the remaining intact structures are not taken up into the blood and lymph fluid. However, the products of ganglioside degradation, such as saccharides and lipids, are supplied to the tissues, where they promote the biosynthesis of gangliosides. In mammals, gangliosides are first degraded in the small intestine by sialidase/neuraminidase, which removes the sialic acid residues [48], and then sequentially degraded into saccharides and ceramides by glycosylceramidase present in the small intestinal mucosa [49]. Ceramides are further degraded into sphingoid bases and free fatty acids by neutral ceramidase [50,51]. These degradation products (saccharides and lipids) are absorbed by small intestinal epithelial cells and then partially re-synthesized into glycosylceramides [7,49]. Gangliosides are thought to be re-synthesized only in tissue cells that express enzymes involved in ganglioside synthesis. The results of these studies indicate that saccharides and lipids derived from gangliosides induce ganglioside expression in tissues. The sialic acid $N$-glycolylneuraminic acid (Neu5Gc), which is found in edible animals but not in humans, is abundant in red meat and dairy products [52]. Consumption of these foods supplies tissue cells with Neu5Gc and results in the synthesis of ganglioside species containing Neu5Gc, which are known to be highly expressed in cancer cells [53].

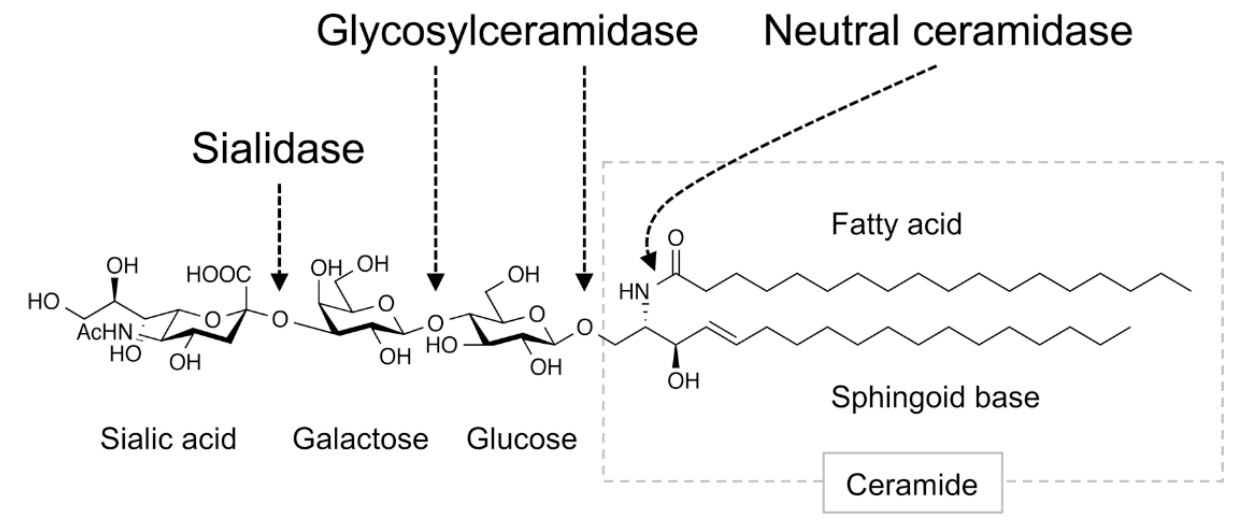

Figure 2. Ganglioside-degradation enzymes in the intestinal tract. Digestive enzymes that degrade gangliosides in the mammalian intestinal tract are shown. Arrows indicate linkage regions in the ganglioside degraded by these enzymes. Figure shows GM3 as an example ganglioside.

Breast milk is a rich source of oligosaccharides containing sialic acid, and the primary oligosaccharide, sialyl lactose, has the same structure as the oligosaccharide of GM3 [8,9]. Infants raised on breast milk have a significantly higher sialic acid content in the gangliosides and glycoproteins in the frontal cortex of the brain than infants fed formula [8]. Sialyl lactose has isomers that exhibit different sialic acid binding patterns, and a model experiment in which pigs were fed these isomers showed that each isomer increases the sialic acid content of gangliosides in a similar manner in several brain regions [9]. These results indicate that the degradation products of sialyl lactose promote ganglioside synthesis in brain tissues. Several animal experiments have shown that a high sialic acid content in gangliosides in the brain is associated with neuronal development, based on the formation and stabilization of functional synapses and neural circuits, leading to improved cognitive function, memory formation, and learning ability [54].

\subsection{Indirect Effects of Dietary Components on Ganglioside Expression}

Several studies have found that ganglioside expression in tissues is affected by various nutrient deficiencies or foods that do not provide components for ganglioside synthesis. A study investigating 
the effects of undernutrition in neonatal rats induced by feeding the mothers a low-protein diet during lactation showed a marked decrease in brain ganglioside content, along with decreases in body and brain weight [55]. Ganglioside expression in neonatal rat brain is also affected by thiamine and vitamin A deficiency [56]. Chronic consumption of ethanol also reportedly affects the expression of gangliosides in the rat brain [57]. Vitamin $\mathrm{K}$ deficiency is known to be associated with cognitive and behavioral perturbations in rats, as well as changes in the expression of gangliosides in the hippocampus, striatal striatum, and prefrontal cortex hippocampus in the rat brain [58]. Another study reported that a high-fat diet decreases glycosphingolipid levels in mouse liver [59], whereas our previous study revealed that ganglioside content in the liver increases in mice fed a high-fat, very-low-carbohydrate ketogenic diet (LCKD) [10,60].

The molecular mechanism underlying indirect induction of ganglioside expression in tissues mediated by dietary components requires further investigation. As considerable research has focused on the molecular mechanism underlying the effects of ketogenic diets on ganglioside expression in tissues, the details will be described in the next section.

\subsection{Dietary Induction of Tissue Ganglioside Expression via Transcriptional Regulation of Ganglioside Metabolism-Related Genes}

Indirect changes in the expression of gangliosides induced by the diet are suggestive of specific changes in the metabolic pathways of ganglioside synthesis and degradation. A number of genes related to ganglioside biosynthesis and metabolism have been identified in recent years, and it has become clear that the expression of gangliosides in tissue cells is regulated by the expression of specific genes, suggesting that transcriptional regulation of ganglioside metabolism-related genes could be targeted by dietary factors that affect tissue ganglioside expression. The molecular species of ganglioside expressed in each type of tissue cell is controlled primarily by the corresponding glycosyltransferase gene. Analyses of the properties of these genes using cultured cells have revealed several targets for modulating ganglioside metabolism, such as transcription factors, signal transduction, and stress responses; controlling these targets thus regulates the expression of gangliosides in cells [1,2].

\subsubsection{Induction of Ganglioside Expression in a Cultured Cell Line by Glucose Starvation}

We previously found that ganglioside expression was increased in cultured cells in which glucose starvation was induced by treatment with 2-deoxyglucose, an inhibitor of glycolysis [61]. This change in expression was correlated with the expression levels of glycosyltransferase genes involved in ganglioside synthesis, suggesting that glucose starvation induced ganglioside expression in these cells via transcriptional control of the related genes. A similar stress response was found to control transcription of the gene encoding the glycosyltransferase that catalyzes synthesis of intracellular glycoproteins $[62,63]$. Thus, we speculated that this is a conserved response to the effects of glucose starvation on the synthesis of glycosphingolipids and glycoproteins in mammalian cells. However, whether a similar response occurs in tissue cells in vivo in response to dietary interventions remains unclear. Our study using cultured cells also showed that levels of neutral glycosphingolipids decreased due to downregulation of the expression of related genes [61,64], indicating that the balance between intracellular metabolism of gangliosides and neutral glycosphingolipids also affects the increased expression of gangliosides brought about by glucose starvation.

\subsubsection{Induction of Tissue Ganglioside Expression in Model Mice Fed a Very-Low-Carbohydrate} Ketogenic Diet

Responses similar to those in cells treated with 2-deoxyglucose can be induced in mice fed a LCKD [65] developed for its antiepileptic effects. We therefore established an LCKD mouse model [66] and analyzed the effect of the LCKD on gene expression in tissues using gene expression profiling [10]. LCKDs are characterized by a specific nutritional balance of reduced glucose content and increased fat content. LCKDs have been shown to suppress even intractable epilepsy resistant 
to currently available antiepileptic drugs, and they have been covered by insurance in Japan since 2016. In addition, recent studies reported beneficial effects of LCKDs in patients with various diseases, including obesity, type 2 diabetes mellitus, autism, cardiomyopathy, neurodegenerative diseases, and cancer [67]. The lipid components of an LCKD are degraded in the liver, and ketone bodies are produced. These ketone bodies are supplied to the tissues as a nutrient in substitution of glucose and used in brain tissues as the only energy source that can be used instead of glucose [68]. In lactating infants, ketone bodies serve as the major nutrient, instead of glucose. We designed an LCKD model using obese mutant mice $(o b / o b)$ to evaluate the diet's effect based on the hyperphagic phenotype of the mice [66]. Furthermore, using $o b / o b$ mice is advantageous because it is easy to detect an increase of hepatic ganglioside expression because the levels of gangliosides in the liver are lower than in wild-type mice $[60,69]$.

A gene expression microarray analysis was conducted using hepatic total RNA from mice fed the LCKD for seven weeks. Numerous genes exhibiting altered expression compared with mice fed regular chow were detected $[10,67,70]$. As expected, genes involved in the synthesis of glycan for gangliosides and glycoproteins exhibited significantly altered transcription in the LCKD-fed mice [10]. Several glycosyltransferase genes involved in ganglioside synthesis were found to be significantly upregulated, including GM3 synthase (St3gal5) and GM2 synthase (B4galnt1), a lack of which has been linked to hereditary epilepsy [31] and spastic paraplegia, respectively [32] (Figure 3). Furthermore, the expression of Gm2a, which encodes the lysosomal GM2 activator protein (GM2AP) required for ganglioside degradation, was also downregulated. These changes suggested that the LCKD increased the levels of gangliosides in the liver. Indeed, the increased ganglioside content in the liver of LCKD-fed mice correlated with the changes in gene expression [10]. The ganglioside content in the liver was more than three times higher than that of chow-fed mice. Furthermore, a similar increase was also observed in serum gangliosides, which are derived from liver gangliosides. An analysis of the ganglioside content in the LCKD used in this study (Bio-Serve F3666) showed that this diet contains GD3 as a major component and GM3 as a minor component. However, GD3 was not detected among the gangliosides in the liver and serum of the mice used in the experiment [10,60], indicating that the gangliosides in the LCKD did not directly affect the expression of gangliosides in the liver and serum of the LCKD-fed mice. The gangliosides contained in the F3666 are mainly derived from butter, a primary ingredient of this diet.

These results and our previous findings indicate that the LCKD indirectly increased tissue expression of gangliosides in mice. As the glycosphingolipid content in the liver is known to decrease in $o b / o b$ mice fed a high-fat diet [59], we conclude that the low-carbohydrate or ketogenic properties of the LCKD induce tissue ganglioside expression. Elucidating the precise molecular mechanism underlying the ganglioside-inducing effects of LCKDs is a subject of our future research. As the expression levels of ganglioside metabolism-related genes are altered in LCKD-fed mice, we will focus on LCKD-mediated transcriptional regulation of these genes.

In brain tissue, a dramatic induction of expression and changes in the structure of gangliosides are observed from the embryonic period to lactation. Ketone bodies derived from the placenta and breast milk are the major nutrients for the fetus and infants [68]; thus, these may significantly affect the changes in ganglioside expression and structure observed during this period. In contrast, fatty liver and hyperglycemia, the major phenotypes of $o b / o b$ mice, are improved by LCKD feeding [66,67]. As increased expression of gangliosides in the liver and serum are correlated with improvements in these pathologies, and gangliosides may play a contributory role.

Long-term LCKD feeding was also shown to affect the glycosylation status of liver glycoproteins [70]. These structural changes in liver glycoproteins were not correlated with the expression levels of glycosyltransferase genes but were correlated with downregulated expression of genes involved in the synthesis of sugar nucleotide donors for protein glycosylation in the liver. This property differed from glycosphingolipid metabolism in the liver of LCKD-fed mice. In other words, the expression levels of liver gangliosides were not correlated with the expression levels 
of genes involved in the synthesis of the sugar nucleotide donors but were correlated with that of glycosyltransferase genes. These results indicate that ganglioside expression depends more on the expression levels of glycosyltransferase genes than on that of genes involved in the synthesis of sugar nucleotide donors. Glycosphingolipids are minor glycoconjugate components compared to glycoproteins in the liver, and the number of donors is presumed to have minimal impact on the synthesis of glycosphingolipids. Differences in the kinetic properties of glycosyltransferases for donors may also affect the production of glycosphingolipids and glycoproteins.

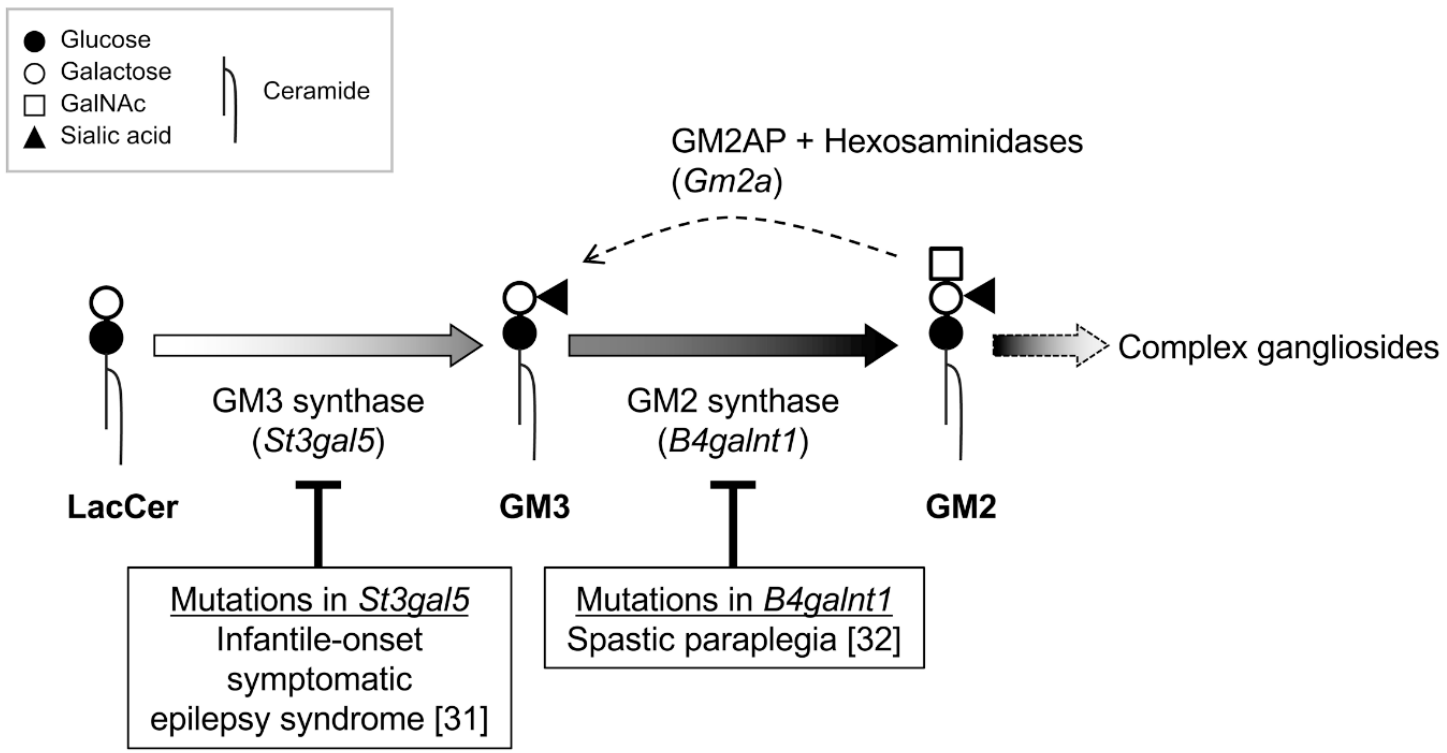

Figure 3. Neurologic disorders associated with mutations in ganglioside synthases. Schematic illustration of the relationship between ganglioside synthesis and mutations in the St3gal 5 and B4galnt1 genes found in infantile-onset symptomatic epilepsy syndrome [31] and spastic paraplegia [32]. Ganglioside GM2 is degraded to GM3 by lysosomal hexosaminidases in concert with GM2 activator protein (GM2AP) (encoded by Gm2a) in lysosomes.

\subsubsection{Effect of LCKD Feeding on Brain Gangliosides}

Gangliosides and their metabolism-related genes regulated by LCKD feeding include those associated with hereditary epilepsy. Gangliosides are expressed primarily in central nervous system tissues, where LCKD feeding exhibits antiepileptic effects. These observations led us to speculate that LCKDs affect the expression of gangliosides in central nervous system tissues. Gene expression analyses in the hippocampus and cerebral cortex, which are considered primary epileptogenic foci, indicated that the effect of LCKDs on gene expression in these tissues is weaker than that in the liver [10]. Among ganglioside metabolism-related genes, we found a significant decrease in the expression level of only Gm2a, as observed in the liver. However, the level of decrease was smaller than that in the liver, and the ganglioside content in these tissues was unchanged by LCKD feeding.

Gm2a-deficient mice exhibit an accumulation of gangliosides in certain brain regions, such as the piriform, entorhinal cortex, amygdala, hypothalamic nuclei, and cerebellum [71]. Thus, we analyzed the effect of LCKD feeding on ganglioside expression in the cerebellum and found that levels of complex gangliosides were significantly increased in LCKD-fed mice [10]. This result indicates that LCKDs affect ganglioside expression in a limited area of central nervous system tissues susceptible to Gm2a.

LCKDs have been shown to suppress refractory epilepsy, which cannot be controlled with currently available drugs [72]. However, the molecular basis of the antiepileptic effect of LCKDs has yet to be fully elucidated. Recent studies have shown that LCKDs exert pleomorphic effects relevant to the nervous system. For example, LCKDs suppress epilepsy by increasing levels of the inhibitory 
neurotransmitter $\gamma$-aminobutyric acid (GABA) [73] or by inhibiting lactate dehydrogenase (LDH) activity in astrocytes and neurons [74]. However, LCKDs appear to have further as yet unidentified effects, as they suppress epilepsy that cannot be controlled with drugs that regulate GABA and LDH.

The GM3 synthase encoded by St3gal5 initiates ganglioside synthesis, and a deficiency in this enzyme results in deficiencies in most gangliosides in vivo [31,75]. In humans, loss of function of the GM3 synthase due to mutations in St3gal5 results in infantile-onset symptomatic epilepsy syndrome [31]. As St3gal5 encodes a sialyltransferase specific for GM3 synthesis and no other function for this protein has been identified, the symptoms of this condition can be attributed to ganglioside deficiency. Loss of function of the GM2 synthase due to mutations in B4galnt1 results in hereditary spastic paraplegia [32]. The complex gangliosides are thought to contribute to the formation of synaptic membranes and regulate neurotransmission via neurotransmitters due to their negative charges $[54,76,77]$. We hypothesize that this property is the molecular basis of the antiepileptic effect of LCKD-induced increased complex ganglioside expression in central nervous system tissue. These observations indicate that increasing the levels of complex gangliosides could be an effective means of protecting against the onset of neurologic diseases. Decreased expression of Gm2a can also contribute to this effect; however, excessive accumulation of gangliosides due to Gm2a deficiency is also associated with the symptoms and onset of epilepsy [78], indicating that modest transcriptional repression of $G m 2 a$, as we observed in LCKD-fed mice, is important. Although any relationship between the findings of this study and epilepsy are purely speculative at present, we believe that these data will contribute to future studies of treatments for epilepsy.

\section{Conclusions}

Progress in biochemistry, molecular biology, nutrition, food science, and glycobiology research has clarified the effects of diet on ganglioside expression in vivo. The scientific studies discussed in this review demonstrated that dietary intake of foods containing gangliosides and its raw materials and dietary interventions to alter the expression of ganglioside metabolism-related genes are means of controlling ganglioside expression in vivo. For continued progress in this field, more information will be required regarding what foods contain gangliosides and the components necessary for their synthesis. Although a number of studies have clarified the mechanism of transcriptional regulation of ganglioside metabolism-related genes in cells, a new approach will be required from the viewpoint of dietary interventions. As little research has been conducted on tissue expression of gangliosides using diet-controlled model animals such as LCKD-fed mice, this will be a major focus of continued research. Many questions remain unanswered in this field; thus, additional studies will be needed to treat and prevent ganglioside-related diseases.

Funding: This work was funded by the Japan Society for the Promotion of Science (JSPS KAKENHI Grant number 15H02907 and 19K11810).

Conflicts of Interest: The author declares no conflicts of interest.

\section{Abbreviations}

$\begin{array}{ll}\text { GSLs } & \text { glycosphingolipids } \\ \text { Neu5Ac } & N \text {-acetylneuraminic acid } \\ \text { Neu5Gc } & N \text {-glycolylneuraminic acid } \\ \text { EGF } & \text { Epidermal growth factor } \\ \text { TAG-1 } & \text { transient axonal glycoprotein-1 } \\ \text { NGF } & \text { nerve growth factor } \\ \text { LCKD } & \text { low-carbohydrate ketogenic diet } \\ \text { ob/ob } & \text { obese mutant } \\ \text { GM2AP } & \text { GM2 activator protein } \\ \text { GABA } & \gamma \text {-aminobutyric acid } \\ \text { LDH } & \text { lactate dehydrogenase }\end{array}$




\section{References}

1. Kolter, T.; Proia, R.L.; Sandhoff, K. Combinatorial ganglioside biosynthesis. J. Biol. Chem. 2002, 277, 25859-25862. [CrossRef]

2. Furukawa, K.; Tokuda, N.; Okuda, T.; Tajima, O.; Furukawa, K. Glycosphingolipids in engineered mice: Insights into function. Semin. Cell Dev. Biol. 2004, 15, 389-396. [CrossRef] [PubMed]

3. Nordström, V.; Willershäuser, M.; Herzer, S.; Rozman, J.; von Bohlen Und Halbach, O.; Meldner, S.; Rothermel, U.; Kaden, S.; Roth, F.C.; Waldeck, C.; et al. Neuronal expression of glucosylceramide synthase in central nervous system regulates body weight and energy homeostasis. PLoS Biol. 2013, 11, e1001506. [CrossRef]

4. Inokuchi, J. GM3 and diabetes. Glycoconj. J. 2014, 31, 193-197. [CrossRef] [PubMed]

5. Schengrund, C.L. Gangliosides: Glycosphingolipids essential for normal neural development and function. Trends Biochem. Sci. 2015, 40, 397-406. [CrossRef] [PubMed]

6. Furukawa, K.; Ohmi, Y.; Ohkawa, Y.; Bhuiyan, R.H.; Zhang, P.; Tajima, O.; Hashimoto, N.; Hamamura, K.; Furukawa, K. New era of research on cancer-associated glycosphingolipids. Cancer Sci. 2019, 110, 1544-1551. [CrossRef]

7. Sugawara, T. Digestion and absorption of sphingolipids as functional food components. J. Jpn. Soc. Nutr. Food Sci. 2013, 66, 177-183. [CrossRef]

8. Wang, B.; McVeagh, P.; Petocz, P.; Brand-Miller, J. Brain ganglioside and glycoprotein sialic acid in breastfed compared with formula-fed infants. Am. J. Clin. Nutr. 2003, 78, 1024-1029. [CrossRef]

9. Jacobi, S.K.; Yatsunenko, T.; Li, D.; Dasgupta, S.; Yu, R.K.; Berg, B.M.; Chichlowski, M.; Odle, J. Dietary isomers of sialyllactose increase ganglioside sialic acid concentrations in the corpus callosum and cerebellum and modulate the colonic microbiota of formula-fed piglets. J. Nutr. 2016, 146, 200-208. [CrossRef]

10. Okuda, T. A low-carbohydrate ketogenic diet promotes ganglioside synthesis via the transcriptional regulation of ganglioside metabolism-related genes. Sci. Rep. 2019, 9, 7627. [CrossRef]

11. Okuda, T.; Fukui, A. Generation of anti-oligosaccharide antibodies that recognize mammalian glycoproteins by immunization with a novel artificial glycosphingolipid. Biochem. Biophys. Res. Commun. 2018, 497,983-989. [CrossRef] [PubMed]

12. Okuda, T. Data on immunoglobulin $\mathrm{G}$ antibodies induced by immunization of mice with globoside carrying very long-chain fatty acids. Data Brief. 2018, 19, 256-260. [CrossRef] [PubMed]

13. Okuda, T.; Shimizu, K.; Hasaba, S.; Date, M. Induction of specific adaptive immune responses by immunization with newly designed artificial glycosphingolipids. Sci. Rep. 2019, 9, 18803. [CrossRef] [PubMed]

14. Okuda, T. Design of carrier molecules suitable for inducing immunity to oligosaccharide antigens: Application to anti-glycoprotein monoclonal antibodies. Trends Glycosci. Glycotechnol. 2018, 30, E113-E116. [CrossRef]

15. Hakomori, S.; Handa, K. GM3 and cancer. Glycoconj. J. 2015, 32, 1-8. [CrossRef]

16. Kasahara, K.; Watanabe, Y.; Yamamoto, T.; Sanai, Y. Association of Src family tyrosine kinase Lyn with ganglioside GD3 in rat brain. Possible regulation of Lyn by glycosphingolipid in caveolae-like domains. J. Biol. Chem. 1997, 272, 29947-29953. [CrossRef]

17. Kasahara, K.; Watanabe, K.; Takeuchi, K.; Kaneko, H.; Oohira, A.; Yamamoto, T.; Sanai, Y. Involvement of gangliosides in glycosylphosphatidylinositol-anchored neuronal cell adhesion molecule TAG-1 signaling in lipid rafts. J. Biol. Chem. 2000, 275, 34701-34709. [CrossRef]

18. Hamamura, K.; Furukawa, K.; Hayashi, T.; Hattori, T.; Nakano, J.; Nakashima, H.; Okuda, T.; Mizutani, H.; Hattori, H.; Ueda, M.; et al. Ganglioside GD3 promotes cell growth and invasion through p130Cas and paxillin in malignant melanoma cells. Proc. Natl. Acad. Sci. USA 2005, 102, 11041-11046. [CrossRef]

19. Kabayama, K.; Sato, T.; Saito, K.; Loberto, N.; Prinetti, A.; Sonnino, S.; Kinjo, M.; Igarashi, Y.; Inokuchi, J. Dissociation of the insulin receptor and caveolin-1 complex by ganglioside GM3 in the state of insulin resistance. Proc. Natl. Acad. Sci. USA 2007, 104, 13678-13683. [CrossRef]

20. Tagami, S.; Inokuchi, J.; Kabayama, K.; Yoshimura, H.; Kitamura, F.; Uemura, S.; Ogawa, C.; Ishii, A.; Saito, M.; Ohtsuka, Y.; et al. Ganglioside GM3 participates in the pathological conditions of insulin resistance. J. Biol. Chem. 2002, 277, 3085-3092. [CrossRef]

21. Mutoh, T.; Tokuda, A.; Miyadai, T.; Hamaguchi, M.; Fujiki, N. Ganglioside GM1 binds to the Trk protein and regulates receptor function. Proc. Natl. Acad. Sci. USA 1995, 92, 5087-5091. [CrossRef] [PubMed] 
22. Nishio, M.; Fukumoto, S.; Furukawa, K.; Ichimura, A.; Miyazaki, H.; Kusunoki, S.; Urano, T.; Furukawa, K. Overexpressed GM1 suppresses nerve growth factor (NGF) signals by modulating the intracellular localization of NGF receptors and membrane fluidity in PC12 cells. J. Biol. Chem. 2004, 279, 33368-33378. [CrossRef] [PubMed]

23. Fukumoto, S.; Mutoh, T.; Hasegawa, T.; Miyazaki, H.; Okada, M.; Goto, G.; Furukawa, K.; Urano, T.; Furukawa, K. GD3 synthase gene expression in PC12 cells results in the continuous activation of TrkA and ERK1/2 and enhanced proliferation. J. Biol. Chem. 2000, 275, 5832-5838. [CrossRef]

24. Ji, S.; Tokizane, K.; Ohkawa, Y.; Ohmi, Y.; Banno, R.; Okajima, T.; Kiyama, H.; Furukawa, K.; Furukawa, K. Increased a-series gangliosides positively regulate leptin/Ob receptor-mediated signals in hypothalamus of GD3 synthase-deficient mice. Biochem. Biophys. Res. Commun. 2016, 479, 453-460. [CrossRef] [PubMed]

25. Ji, S.; Ohkawa, Y.; Tokizane, K.; Ohmi, Y.; Banno, R.; Furukawa, K.; Kiyama, H.; Furukawa, K. b-Series gangliosides crucially regulate leptin secretion in adipose tissues. Biochem. Biophys. Res. Commun. 2015, 459, 189-195. [CrossRef] [PubMed]

26. Herzer, S.; Meldner, S.; Gröne, H.J.; Nordström, V. Fasting-induced lipolysis and hypothalamic insulin signaling are regulated by neuronal glucosylceramide synthase. Diabetes 2015, 64, 3363-3376. [CrossRef]

27. Kondo, Y.; Ikeda, K.; Tokuda, N.; Nishitani, C.; Ohto, U.; Akashi-Takamura, S.; Ito, Y.; Uchikawa, M.; Kuroki, Y.; Taguchi, R.; et al. TLR4-MD-2 complex is negatively regulated by an endogenous ligand, globotetraosylceramide. Proc. Natl. Acad. Sci. USA 2013, 110, 4714-4719. [CrossRef]

28. Rossjohn, J.; Pellicci, D.G.; Patel, O.; Gapin, L.; Godfrey, D. Recognition of CD1d-restricted antigens by natural killer T cells. Nat. Rev. Immunol. 2012, 12, 845-857. [CrossRef]

29. Nagafuku, M.; Okuyama, K.; Onimaru, Y.; Suzuki, A.; Odagiri, Y.; Yamashita, T.; Iwasaki, K.; Fujiwara, M.; Takayanagi, M.; Ohno, I.; et al. CD4 and CD8 T cells require different membrane gangliosides for activation. Proc. Natl. Acad. Sci. USA 2012, 109, E336-E342. [CrossRef]

30. Sandhoff, K.; Harzer, K. Gangliosides and gangliosidoses: Principles of molecular and metabolic pathogenesis. J. Neurosci. 2013, 33, 10195-10208. [CrossRef]

31. Simpson, M.A.; Cross, H.; Proukakis, C.; Priestman, D.A.; Neville, D.C.; Reinkensmeier, G.; Wang, H.; Wiznitzer, M.; Gurtz, K.; Verganelaki, A.; et al. Infantile-onset symptomatic epilepsy syndrome caused by a homozygous loss-of-function mutation of GM3 synthase. Nat. Genet. 2004, 36, 1225-1229. [CrossRef] [PubMed]

32. Harlalka, G.V.; Lehman, A.; Chioza, B.; Baple, E.L.; Maroofian, R.; Cross, H.; Sreekantan-Nair, A.; Priestman, D.A.; Al-Turki, S.; McEntagart, M.E.; et al. Mutations in B4GALNT1 (GM2 synthase) underlie a new disorder of ganglioside biosynthesis. Brain 2013, 136, 3618-3624. [CrossRef] [PubMed]

33. Yanagisawa, K. GM1 ganglioside and Alzheimer's disease. Glycoconj. J. 2015, 32, 87-91. [CrossRef] [PubMed]

34. Binz, T.; Rummel, A. Cell entry strategy of clostridial neurotoxins. J. Neurochem. 2009, 109, 1584-1595. [CrossRef] [PubMed]

35. Hakomori, S. Glycosylation defining cancer malignancy: New wine in an old bottle. Proc. Natl. Acad. Sci. USA 2002, 99, 10231-10233. [CrossRef] [PubMed]

36. Takamizawa, K.; Iwamori, M.; Mutai, M.; Nagai, Y. Gangliosides of bovine buttermilk. Isolation and characterization of a novel monosialoganglioside with a new branching structure. J. Biol. Chem. 1986, 261, 5625-5630.

37. Fong, B.Y.; Ma, L.; Khor, G.L.; van der Does, Y.; Rowan, A.; McJarrow, P.; MacGibbon, A.K. Ganglioside composition in beef, chicken, pork, and fish determined using liquid chromatography-high-resolution mass spectrometry. J. Agric. Food Chem. 2016, 64, 6295-6305. [CrossRef]

38. Pham, P.H.; Duffy, T.L.; Dmytrash, A.L.; Lien, V.W.; Thomson, A.B.; Clandinin, M.T. Estimate of dietary ganglioside intake in a group of healthy Edmontonians based on selected foods. J. Food Compos. Anal. 2011, 24, 1032-1037. [CrossRef]

39. Takamizawa, K.; Iwamori, M.; Mutai, M.; Nagai, Y. Selective changes in gangliosides of human milk during lactation: A molecular indicator for the period of lactation. Biochim. Biophys. Acta 1986, 879, 73-77.

40. Martín-Sosa, S.; Martín, M.J.; Castro, M.D.; Cabezas, J.A.; Hueso, P. Lactational changes in the fatty acid composition of human milk gangliosides. Lipids 2004, 39, 111-116. [CrossRef]

41. Laegreid, A.; Kolstø Otnaess, A.B. Trace amounts of ganglioside GM1 in human milk inhibit enterotoxins from Vibrio cholerae and Escherichia coli. Life Sci. 1987, 40, 55-62. [CrossRef] 
42. Rueda, R.; Puente, R.; Hueso, P.; Maldonado, J.; Gil, A. New data on content and distribution of gangliosides in human milk. Biol. Chem. Hoppe Seyler 1995, 376, 723-727. [CrossRef] [PubMed]

43. Pan, X.L.; Izumi, T. Variation of the ganglioside compositions of human milk, cow's milk and infant formulas. Early Hum. Dev. 2000, 57, 25-31. [CrossRef]

44. Zhang, J.; Ren, Y.; Huang, B.; Tao, B.; Pedersen, M.R.; Li, D. Determination of disialoganglioside GD3 and monosialoganglioside GM3 in infant formulas and whey protein concentrates by ultra-performance liquid chromatography/electrospray ionization tandem mass spectrometry. J. Sep. Sci. 2012, 35, 937-946. [CrossRef] [PubMed]

45. Salcedo, J.; Karav, S.; Le Parc, A.; Cohen, J.L.; de Moura Bell, J.M.L.N.; Sun, A.; Lange, M.C.; Barile, D. Application of industrial treatments to donor human milk: Influence of pasteurization treatments, storage temperature, and time on human milk gangliosides. NPJ Sci. Food. 2018, 2, 5. [CrossRef]

46. Sugawara, T.; Miyazawa, T. Separation and determination of glycolipids from edible plant sources by high-performance liquid chromatography and evaporative light-scattering detection. Lipids 1999, 34, 1231. [CrossRef]

47. Uchiyama, T.; Nakano, Y.; Ueda, O.; Mori, H.; Nakashima, M.; Noda, A.; Ishizaki, C.; Mizoguchi, M. Oral Intake of Glucosylceramide Improves Relatively Higher Level of Transepidermal Water Loss in Mice and Healthy Human Subjects. J. Health Sci. 2008, 54, 559-566. [CrossRef]

48. Dickson, J.J.; Messer, M. Intestinal neuraminidase activity of suckling rats and other mammals. Relationship to the sialic acid content of milk. Biochem. J. 1978, 170, 407-413. [CrossRef]

49. Nilsson, A. Metabolism of cerebroside in the intestinal tract of the rat. Biochim. Biophys. Acta 1969, 187, 113-121. [CrossRef]

50. Nilsson, A. The presence of spingomyelin- and ceramide-cleaving enzymes in the small intestinal tract. Biochim. Biophys. Acta 1969, 176, 339-347. [CrossRef]

51. Olsson, M.; Duan, R.D.; Ohlsson, L.; Nilsson, A. Rat intestinal ceramidase: Purification, properties, and physiological relevance. Am. J. Physiol. Gastrointest. Liver Physiol. 2004, 287, 929-937. [CrossRef] [PubMed]

52. Tangvoranuntakul, P.; Gagneux, P.; Diaz, S.; Bardor, M.; Varki, N.; Varki, A.; Muchmore, E. Human uptake and incorporation of an immunogenic nonhuman dietary sialic acid. Proc. Natl. Acad. Sci. USA 2003, 100, 12045-12050. [CrossRef] [PubMed]

53. Miyoshi, I.; Higashi, H.; Hirabayashi, Y.; Kato, S.; Naiki, M. Detection of 4-O-acetyl-N-glycolylneuraminyl lactosylceramide as one of tumor-associated antigens in human colon cancer tissues by specific antibody. Mol. Immunol. 1986, 23, 631-638. [CrossRef]

54. Palmano, K.; Rowan, A.; Guillermo, R.; Guan, J.; McJarrow, P. The role of gangliosides in neurodevelopment. Nutrients 2015, 7, 3891-3913. [CrossRef] [PubMed]

55. Vaswani, K.K.; Sharma, M. Effect of neonatal undernutrition on rat brain gangliosides. Int. J. Vitam. Nutr. Res. 1985, 55, 323-329.

56. Vaswani, K.K. Effect of neonatal thiamine and vitamin A deficiency on rat brain gangliosides. Life Sci. 1985, 37, 1107-1115. [CrossRef]

57. Vrbaski, S.R.; Grujić-Injac, B.; Ristić, M. Phospholipid and ganglioside composition in rat brain after chronic intake of ethanol. J. Neurochem. 1984, 42, 1235-1239. [CrossRef]

58. Tamadon-Nejad, S.; Ouliass, B.; Rochford, J.; Ferland, G. Vitamin K deficiency induced by warfarin is associated with cognitive and behavioral perturbations, and alterations in brain sphingolipids in rats. Front. Aging Neurosci. 2018, 10, 213. [CrossRef]

59. Eisinger, K.; Krautbauer, S.; Hebel, T.; Schmitz, G.; Aslanidis, C.; Liebisch, G.; Buechler, C. Lipidomic analysis of the liver from high-fat diet induced obese mice identifies changes in multiple lipid classes. Exp. Mol. Pathol. 2014, 97, 37-43. [CrossRef]

60. Okuda, T.; Morita, N. A very low carbohydrate ketogenic diet increases hepatic glycosphingolipids related to regulation of insulin signaling. J. Funct. Foods 2016, 21, 70-74. [CrossRef]

61. Okuda, T.; Furukawa, K.; Nakayama, K. A novel, promoter-based, target-specific assay identifies 2-deoxy-D-glucose as an inhibitor of globotriaosylceramide biosynthesis. FEBS J. 2009, 276, 5191-5202. [CrossRef] [PubMed]

62. Okuda, T.; Fukui, A.; Morita, N. Altered expression of $O$-GlcNAc-modified proteins in a mouse model whose glycemic status is controlled by a low carbohydrate ketogenic diet. Glycoconj. J. 2013, 30, 781-789. [CrossRef] [PubMed] 
63. Okuda, T. Western blot data using two distinct anti-O-GlcNAc monoclonal antibodies showing unique glycosylation status on cellular proteins under 2-deoxy-D-glucose treatment. Data Brief 2016, 10, 449-453. [CrossRef] [PubMed]

64. Okuda, T.; Nakayama, K. Identification and characterization of the human Gb3/CD77 synthase gene promoter. Glycobiology 2008, 18, 1028-1035. [CrossRef]

65. Garriga-Canut, M.; Schoenike, B.; Qazi, R.; Bergendahl, K.; Daley, T.J.; Pfender, R.M.; Morrison, J.F.; Ockuly, J.; Stafstrom, C.; Sutula, T.; et al. 2-Deoxy-D-glucose reduces epilepsy progression by NRSF-CtBP-dependent metabolic regulation of chromatin structure. Nat. Neurosci. 2006, 9, 1382-1387. [CrossRef]

66. Okuda, T.; Morita, N. A very low carbohydrate ketogenic diet prevents the progression of hepatic steatosis caused by hyperglycemia in a juvenile obese mouse model. Nutr. Diabetes 2012, 2, e50. [CrossRef]

67. Okuda, T. A low-carbohydrate ketogenic diet induces the expression of very-low-density lipoprotein receptor in liver and affects its associated metabolic abnormalities. NPJ Sci. Food 2019, 3, 25. [CrossRef]

68. Vannucci, S.J.; Simpson, I.A. Developmental switch in brain nutrient transporter expression in the rat. Am. J. Physiol. Endocrinol. Metab. 2003, 285, 1127-1134. [CrossRef]

69. Sena, A.; Rebel, G.; Bieth, R.; Hubert, P.; Waksman, A. Lipid composition in liver and brain of genetically obese $(o b / o b)$, heterozygote $(o b /+)$ and normal (+/+) mice. Biochim. Biophys. Acta 1982, 710, 290-296. [CrossRef]

70. Okuda, T. Data set for characterization of the glycosylation status of hepatic glycoproteins in mice fed a low-carbohydrate ketogenic diet. Data Brief 2019, 27, 104604. [CrossRef]

71. Liu, Y.; Hoffmann, A.; Grinberg, A.; Westphal, H.; McDonald, M.P.; Miller, K.M.; Crawley, J.N.; Sandhoff, K.; Suzuki, K.; Proia, R.L. Mouse model of GM2 activator deficiency manifests cerebellar pathology and motor impairment. Proc. Natl. Acad. Sci. USA 1997, 94, 8138-8143. [CrossRef] [PubMed]

72. Gano, L.B.; Patel, M.; Rho, J.M. Ketogenic diets, mitochondria, and neurological diseases. J. Lipid Res. 2014, 55, 2211-2228. [CrossRef] [PubMed]

73. Yudkoff, M.; Daikhin, Y.; Nissim, I.; Horyn, O.; Lazarow, A.; Luhovyy, B.; Wehrli, S.; Nissim, I. Response of brain amino acid metabolism to ketosis. Neurochem. Int. 2005, 47, 119-128. [CrossRef] [PubMed]

74. Sada, N.; Lee, S.; Katsu, T.; Otsuki, T.; Inoue, T. Epilepsy treatment. Targeting LDH enzymes with a stiripentol analog to treat epilepsy. Science 2015, 347, 1362-1367. [CrossRef] [PubMed]

75. Yamashita, T.; Hashiramoto, A.; Haluzik, M.; Mizukami, H.; Beck, S.; Norton, A.; Kono, M.; Tsuji, S.; Daniotti, J.L.; Werth, N.; et al. Enhanced insulin sensitivity in mice lacking ganglioside GM3. Proc. Natl. Acad. Sci. USA 2003, 100, 3445-3449. [CrossRef] [PubMed]

76. Ochoa, E.L.; Bangham, A.D. N-Acetylneuraminic acid molecules as possible serotonin binding sites. J. Neurochem. 1976, 26, 1193-1198. [CrossRef] [PubMed]

77. Juhola, H.; Postila, P.A.; Rissanen, S.; Lolicato, F.; Vattulainen, I.; Róg, T. Negatively Charged Gangliosides Promote Membrane Association of Amphipathic Neurotransmitters. Neuroscience 2018, 384, $214-223$. [CrossRef]

78. Martins, C.; Brunel-Guitton, C.; Lortie, A.; Gauvin, F.; Morales, C.R.; Mitchell, G.A.; Pshezhetsky, A.V. Atypical juvenile presentation of GM2 gangliosidosis AB in a patient compound-heterozygote for c.259G > T and c.164C > T mutations in the GM2A gene. Mol. Genet. Metab. Rep. 2017, 11, 24-29. [CrossRef]

(C) 2019 by the author. Licensee MDPI, Basel, Switzerland. This article is an open access article distributed under the terms and conditions of the Creative Commons Attribution (CC BY) license (http://creativecommons.org/licenses/by/4.0/). 